\title{
Dynamics of Food Price Volatility and Households' Welfare in Nigeria
}

\author{
Onwusiribe Ndubuisi Chigozirim, Nto Philips Okore, Oteh Ogbonnaya Ukeh, Agwu Nnanna Mba \\ Department of Agribusiness and Management, Michael Okpara University of Agriculture Umudike, Abia \\ State, Nigeria
}

\begin{abstract}
One of the most important economic factors in food choice is the price. Food dynamics' value is a subject of controversies and opinions, especially price issues, and sensitivity is often peculiar to seasons and market forces. Price dynamics have the potential to introduce and change consumptions, thus affecting household welfare. This study examined the dynamics of food price volatility and households' welfare in Nigeria from 1990: Q1 to 2019: Q4. We sourced the study data from the Food and Agriculture Organization (FAO) and the World Bank (WB). We estimated the quadratic trend equation, Generalized Autoregressive Conditional Heteroscedasticity (GARCH), and Auto-Regressive Distributed Lag (ARDL) models. Food prices and depth of food deficit had a significant short-run impact on the households' welfare. Policymakers should focus on the short-term benefits while formulating policies aimed at households' welfare because policies aimed at the household level are impactful in the short-run compared to the long-run.
\end{abstract}

\section{Keywords}

Food, price, household, welfare, volatility.

Chigozirim, O. N., Okore, N. P., Ukeh, O. O. and Mba, A. N. (2021) "Dynamics of Food Price Volatility and Households' Welfare in Nigeria", AGRIS on-line Papers in Economics and Informatics, Vol. 13, No. 4, pp. 49-60. ISSN 1804-1930. DOI 10.7160/aol.2021.130405.

\section{Introduction}

One of the primary goals of economic development in the actual term is to improve household welfare. In Nigeria, although economic indicator based on 2019 reports from both World Bank and African Development Bank (AfDB) shows that she is the largest economy in Africa with a Gross Domestic Product of $\$ 446.543$ billion and GDP growth rate of $2.3 \%$, evidence indicates that Nigeria has the highest number of poor people globally, with most of the population struggling to survive on less than \$2 daily. Poverty has economic and social implications such as productivity, food production and price, and household welfare. Nigeria's challenge is complicated because, over the year, there is a gap between food production and population growth, leading to an increase in food prices and the diversity of hungry people. National Social Register of Poor and Vulnerable Households (PVHHs) published that 2, 644, 495 households live in poverty with 11, 045537 individuals (NSIP, 2020). About 42,912,900 households and 200,963,600 million people make up the population of Nigeria thrive on insufficient food; the statistics imply that 5.5 per cent of the entire Nigerian population is poor and vulnerable and can barely afford three portions of food per day. Since Nigeria is a food deficit country, and there is an ever-increasing demand for food, supply, and demand law play a significant role in food price determination. Therefore, rising food costs take the most substantial proportion of low to middle-income households, affecting these households' capacity to meet their other welfare needs. The welfare of households largely depends on the quantity and quality of food consumed. Amongst other welfare indicators such as shelter, health care, education, access to essential utilities like electricity and water, food is pivotal in determining individual and household welfare; hence it is at the centre of global Sustainable Development Goals (SDGs).

In recent times, global food demand and other agricultural products' uses put pressure on food production, leading to a sharp increase in food prices in both international and national markets. The susceptibility of food prices to changes exposes the fragile nature of the global food system. Therefore, addressing this has continued to command the interest of policymakers because food price is an essential aspect of inflation, and inflation affects households' consumption expenditure. Although global food commodity price has been on the decline since 2008, 
in Nigeria, the reverse is the case as food prices have conti increased (SIA/FAO, 2008; PinstrupAndersen, 2015). Although the food deficit levels in other Sub-Saharan African countries are severe, and Nigeria will endure if the situation worsens (Ojo and Adebayo, 2012). Factors such as the high level of dependence of agriculture on rainfall, a low level of mechanisation, no automation, and small value addition have negatively affected Nigeria's food production due to exposure to dynamics of global trade and exchange rate vagaries. The most important crops in Nigeria include rice, cowpeas, beans, wheat, yam, cocoyam, cassava, vegetables, and palm oil with a good value chain capable of improving households' welfare through job creation and nutrition (PARI, 2015).

Evidence from several studies shows that household welfare is more tested correctly in terms of household consumption per capita and expenditure, including other well-being measures such as food security and household asset holding (ICRW, 2017; Moratti \& Natali, 2012). Household consumption expenditure reflects their welfare status, and it reveals the portion of income and returns on investments (assets) that the households are willing and able to spend on food, education, and basic amenities that make up their welfare. These are more accurately predicted and measured using price changes in any given market and society since there is a nexus between a price change and household consumption expenditure and overall welfare.

Price volatility is the changes in the price of a commodity, and it measures price changes between specific periods (IFPRI, 2011; FAO and OECD, 2011). The continuous rise in food prices has many severe consequences on individuals' welfare and may lead to food riots, unrest, and crime (Braun, 2008). Although the food price increase is not peculiar to Nigeria like other developing countries, it has exacerbated due to its population growth. The population growth rate of 2.6 per cent causes insufficient food (World Bank, 2019). The population's geometric growth has dire consequences on the price of food products, affecting households' welfare. Food price volatility may not be problematic, mainly when the variation follows a known trend and market conditions. However, changes in food prices become an issue of worry when there are distortions in the trend. Such worrisome distortions affect the farmers, value chain actors, and households. Food price is an essential variable in household income and consumption decisions; price levels and fluctuations in food commodities' prices affect household income and consumption (Diaz-Bonilla, 2016).

The nexus between post-war periods, post-pandemic periods or post-political crises and food demand holds strong potential for food price volatility. For instance, evidence shows that the outbreak of Nigerian civil war in 1967 and the resultant agricultural challenges and the food blockade of the region occupied by secessionist Biafra led to food price volatility after the war (Iwuagwu, 2012), resulting in high food insecurity in Southeast Nigeria. With the recent coronavirus pandemic (COVID-19) that has disrupted the livelihood of many households and food supply chains, it has become imperative to study the trend of food prices, household welfare, and understand the impact of food prices on households' welfare.

\section{Materials and methods}

We sourced the data for this study from the Food and Agriculture Organization (FAO) database and World Development Indicators (WDI) of the World Bank. The data covered a period of 1990: Q1 to 2019: Q4. We used the quadratic trend equation, generalised Autoregressive Conditional Heteroscedasticity (GARCH) model, and the Auto-Regressive Distributed Lag (ARDL) model regression approach for the data analysis.

\section{Model specification}

\section{Trend Aaalysis}

The log quadratic trend equation, which shows either the acceleration, stagnation or deceleration of the time series data, is specified.

$$
\begin{aligned}
& \ln A V P I F=a+b_{1} t+b_{2} t^{2}+u_{i} \\
& \ln H H W=a+b_{1} t+b_{2} t^{2}+u_{i}
\end{aligned}
$$

Where AVPIF is the average price of selected food commodities in Naira, HHW is the Household welfare (Household final consumption expenditure (N)), a is the constant, $t$ is the time, $b$ is the coefficient of time, and $\ln$ is the natural $\log$ and $u_{i}$ is the error term.

\section{The Generalised Autoregressive Conditional Heteroskedasticity (GARCH)}

Time series data, such as food prices, are volatile, heteroscedasticity, and leptokurtic (Popović, 2011). To address this, we adopt the GARCH model, as expressed by Bollerslev (1986). The standard $\operatorname{GARCH}(p, q)$ specification; 


$$
y_{t}=a+\sum_{i=1}^{k} \quad n_{i} x_{t}-1 \varepsilon_{t}
$$

Where $y_{t}$ is a measure of food price volatility at time $t, \mathrm{a}$ is the mean, $x_{t-1}$ is the exogenous variables, and $\varepsilon_{t}$ is the error term.

$$
\delta=\sqrt{\frac{1}{N} \sum_{i=1}^{k}\left(X_{i}-\bar{X}\right)}
$$

Where $\delta$ is the variance, $x_{i}$ is the mean and $\bar{X}$ is the mean deviation.

$$
\delta t^{2}=\omega+\sum_{i=1}^{p} \text { ai } \epsilon_{t-i}^{2}+\sum_{i=1}^{q} \beta_{i} \delta_{t-i}^{2}
$$

Where $\delta^{t 2}$ is the conditional variance, $p$ is the order of the GARCH, and $\delta_{t-i}{ }^{2}$ is the GARCH term.

\section{The Auto-Regressive Distributed Lag Model}

We estimate the Auto-Regressive Distributed Lag (ARDL) model, also referred to as the bounds testing approach to co-integration, in line with Pesaran et al. (2001) to examine the dynamics of food price volatility and household welfare. The ARDL applies on time series data with the order of integration I (0) and I (1) (i.e., Mixed order of the order of integration) and results in an unbiased long-run estimate, where a long-run relationship exists (Bawa et al., 2016; Udo et al., 2015). We estimated the model as follows.

$$
\begin{aligned}
& H H W=c_{0}+\delta_{1} H H W_{t-1}+\delta_{2} C_{P I F_{t-1}}+ \\
& +\delta_{3} A V P I F_{t-1}+\delta_{4} D F D_{t-1}+\delta_{5} A C F_{t-1}+ \\
& +\delta_{6} E L E_{t-1}+\delta_{7} E M P_{t-1}+\delta_{8} F E_{t-1}+ \\
& +\delta_{9} F I_{t-1}+\delta_{10} F P I_{t-1}+\sum_{i=1}^{p 4} b_{1} H H W_{t-1}+ \\
& +\sum_{i=0}^{p} b_{2} C P I F_{t-1}+\sum_{i=0}^{p 1} b_{3} A V P I F_{t-1}+ \\
& +\sum_{i=0}^{p 4} b_{4} D F D_{t-1}+\sum_{i=0}^{p} b_{5} A C F_{t-1}+ \\
& +\sum_{i=0}^{p} b_{6} E L E_{t-1}+\sum_{i=0}^{p 1} b_{7} E M P_{t-1}+ \\
& +\sum_{i=0}^{p} b_{8} F E_{t-1}+\sum_{i=0}^{p 4} b_{9} F I_{t-1}+ \\
& +\sum_{i=0}^{p} b_{10} F P I_{t-1}+\varepsilon_{t}
\end{aligned}
$$

Where $\delta_{i}$ represent the long-run multipliers, $c_{o}$ is the constant, bi is the coefficients, $p$ is the lag length, $H H W$ is the household welfare (Household final consumption expenditure ( $(\mathbb{N})$ ), CPIF is the Consumer Prices, Food Indices, AVPIF is the average producer price of selected essential food commodities ( $\$$ (i.e. beans, cassava, cocoyam, cowpea, millet, palm oil, rice, vegetables, wheat and yam), ELE is the access to electricity ( $\%$ of the population in millions), DFD is the depth of food deficit (kilocalories per person), ACF is the access to cooking fuel ( $\%$ of the population in millions), EMP is the employment status ( $\%$ of the population in millions), FPI is the food production index $(2004-2006=100), F I$ is the food import (\% of merchandise import), FE is the food export ( $\%$ of merchandise export), is the summation sign, and et is the error term. We sourced HHW, ELE, ACF, EMP, FE, FI and DFD from World Development Indicators while we sourced AVPIF and CPIF sourced from the Food and Agriculture Organization database.

We conducted the ARDL bound test following equation (6) to test for the existence of a long-run relationship. We tested the following hypotheses.

$\mathrm{H}_{0}=$ the long-run multipliers are not significantly different from zero $\left(\mathrm{H}_{0}=\delta_{1}=\delta_{2}=\delta_{3}=\delta_{4}=\delta_{5}=\delta_{6}\right.$ $=\delta_{7}=\delta_{8}=\delta_{9}=\delta_{10}=0$ )

$\mathrm{H}_{\mathrm{a}}=$ the long-run multipliers are significantly different from zero $\left(\mathrm{H}_{\mathrm{a}}=\delta_{1} \neq \delta_{2} \neq \delta_{3} \neq \delta_{4} \neq \delta_{5} \neq \delta_{6}\right.$ $\neq \delta_{7} \neq \delta_{2} \neq \delta_{8} \neq \delta_{9} \neq \delta_{10} \neq 0$ )

We made use of the tabulated asymptotic critical valued bound by Pesaran et al. (2001), which provide a test for co-integration with $\mathrm{I}(0)$ and $\mathrm{I}(1)$ lower and upper boundaries, respectively. If the F-calculated value falls within or equal to the tabulated values, it suggests a long-run relationship; otherwise, it implies that only short-run relationships exist. Since there was co-integration among the variables, we estimate the conditional ARDL model.

$$
\begin{aligned}
& H H W=c_{0}+\sum_{i=1}^{p 4} b_{1} H H W_{t-1}+\sum_{i=0}^{p} b_{2} C P I F_{t-1}+ \\
& +\sum_{i=0}^{p 1} b_{3} A V P I F_{t-1}+\sum_{i=0}^{p 4} b_{4} D F D_{t-1}+ \\
& +\sum_{i=0}^{p} b_{5} A C F_{t-1}+\sum_{i=0}^{p} b_{6} E L E_{t-1}+ \\
& +\sum_{i=0} b_{7} E M P_{t-1}+\sum_{i=0} b_{8} F E_{t-1}+ \\
& +\sum_{i=0} b_{9} F I_{t-1}+\sum_{i=0} b_{10} F P I_{t-1}+\mu_{t}
\end{aligned}
$$

We got the short-run dynamic parameters by estimating the error correction model. 


$$
\begin{gathered}
\Delta H H W=c_{0}+\sum_{i=1}^{p 4} b_{1} \Delta H H W_{t-1}+\sum_{i=0}^{p} b_{2} \Delta C P I F_{t-1}+ \\
+\sum_{i=0}^{p 1} b_{3} \Delta A V P I F_{t-1}+\sum_{i=0}^{p 4} b_{4} \Delta D F D_{t-1}+ \\
+\sum_{i=0} b_{5} \Delta A C F_{t-1}+\sum_{i=0} b_{6} \Delta E L E_{t-1}+ \\
+\sum_{i=0} b_{7} \Delta E M P_{t-1}+\sum_{i=0} b_{8} \Delta F E_{t-1}+ \\
+\sum_{i=0} b_{9} \Delta F I_{t-1}+\sum_{i=0} b_{10} \Delta F P I_{t-1}+\text { vecm }_{t-1}
\end{gathered}
$$

Where ECM is the error correction term of equation (6) and $\vartheta$ is the speed of adjustment.

\section{Results and discussion}

Unit root tests results and trend in the price of selected food commodities

We tested the properties of the time-series data used for the analysis. We used Phillips-Peron (1988) test (P.P.) in determining the stationary of the variables under consideration, and we presented the results in Table 1. The unit root tests revealed that all the variables considered in this study were stationary at first difference.

From the Table 1, the entire test variables for the assessment of food price volatility on the welfare of households in Nigeria were stationary at the first difference based on the P.P. test statistics. One could reject the null hypothesis of nonstationary. The occurrence of unit roots in the data generation preliminarily shows shocks having a permanent or long-lasting effect.

There has been considerable variability and instability in the prices of these food commodities. We relate this to the global hike in food price to the trend, and it shows that the prices of the selected food commodities have grown from the first quarter of 1990 before hitting the peak in the last quarter of 2007 (FAO, 2017). As shown in Figure 1, sharp growth, continuous fluctuations, and a sharp decline characterised the general trend pattern for cassava, cowpea, rice, wheat, palm oil, cocoyam, beans, vegetable, and yam for the period under study.

Egwuma, Ojeleye, and Adeolu (2017) reported that food inflation has increased with it influencing other macroeconomic variables. Taru (2014) said

\begin{tabular}{lccc}
\hline Variables & Level & First difference & Decision \\
\hline Access to cooking fuel and gas & -1.911024 & -10.77033 & $\mathrm{I}(1)$ \\
Average price of the selected food items in Naira (per ton) & -2.201370 & -8.905442 & $\mathrm{I}(1)$ \\
Depth of food deficit & -2.146940 & -11.24664 & $\mathrm{I}(1)$ \\
Access to electricity & -1.300126 & -10.79099 & $\mathrm{I}(1)$ \\
Employment status & 3.984839 & -17.21190 & $\mathrm{I}(1)$ \\
Food export & -2.663116 & -11.47534 & $\mathrm{I}(0), \mathrm{I}(1)$ \\
Food import & -2.732243 & -10.78255 & $\mathrm{I}(0), \mathrm{I}(1)$ \\
Food production index & -1.413168 & -10.78326 & $\mathrm{I}(1)$ \\
Household Welfare & -1.575734 & -10.81241 & $\mathrm{I}(1)$ \\
Consumer Price index (Food indices) & -3.672372 & -11.28320 & $\mathrm{I}(0), \mathrm{I}(1)$ \\
Price of Beans in Naira (per ton) & -2.106437 & -10.96121 & $\mathrm{I}(1)$ \\
Price of cassava in Naira (per ton) & -1.604460 & -10.90058 & $\mathrm{I}(1)$ \\
Price of Cocoyam (per ton) & -1.720703 & -10.77033 & $\mathrm{I}(1)$ \\
Price of Cowpea in Naira (per ton) & -2.125041 & -11.52827 & $\mathrm{I}(1)$ \\
Price of Millet in Naira (per ton) & -1.897739 & -11.40523 & $\mathrm{I}(1)$ \\
Price of palm oil in Naira (per ton) & -1.565957 & -10.77033 & $\mathrm{I}(1)$ \\
Price of rice in Naira (per ton) & -1.757772 & -10.93934 & $\mathrm{I}(1)$ \\
Price of vegetable in Naira (per ton) & -1.553928 & -10.77033 & $\mathrm{I}(1)$ \\
Price of wheat in Naira (per ton) & -1.509354 & -10.77970 & $\mathrm{I}(1)$ \\
Price of yam in Naira (per ton) & -1.586433 & -10.81144 & $\mathrm{I}(1)$ \\
\hline
\end{tabular}

Source: World development indicators and FAO data in various years 


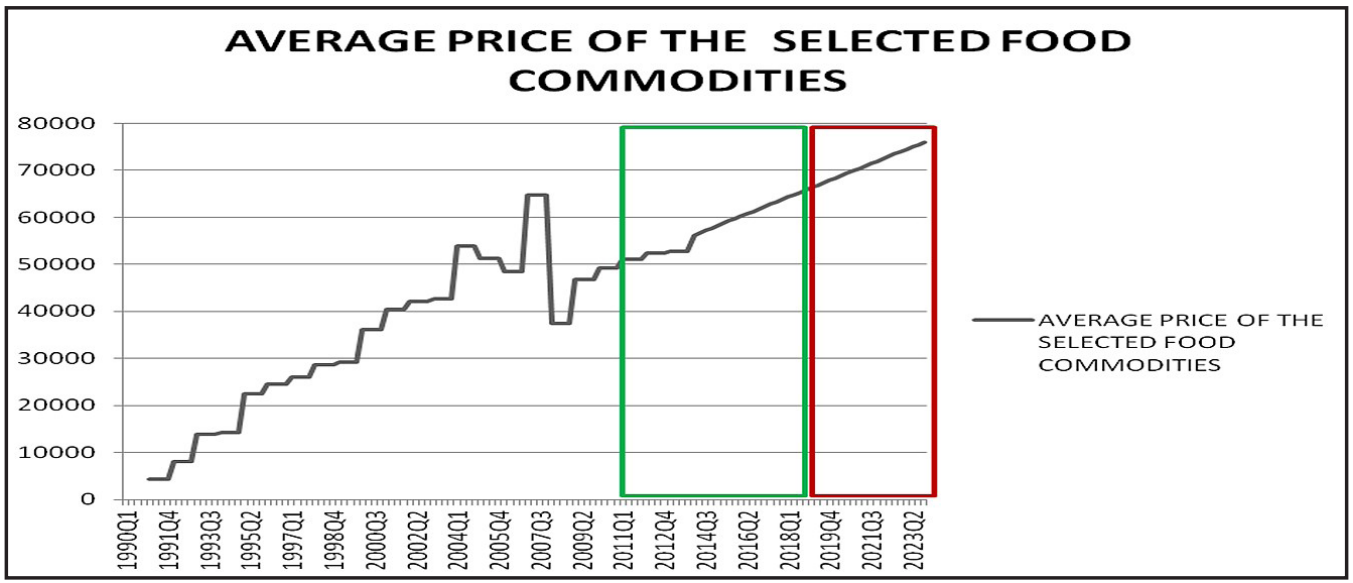

Note: Portion bounded in green are estimates while portion bounded in red are forecasts Source: Authors' analysis based on FAO, 2020.

Figure 1: Trend in the average price of selected food commodities in Nigeria.

that cereals, such as rice, have been fluctuating over the years and very volatile. He reported that seasonal factors were responsible for the volatility in price. Compton, Keats, and Wiggins (2010) argued that the increase in the oil price affected the food prices in oil-producing economies such as Nigeria because of excess foreign reserves available for food importation. The sharp decrease in the prices of food in 2012:Q4 is because of the increased funding of agriculture through the Agricultural Transformation Agenda (ATA) and NIRSAL that lead to the increase in food production; the rise in food production forced the prices of food to go down (Olomola and Nwafor, 2018).

Estimated growth in the trend of household welfare and cause of the average price of the selected food commodities

Table 2 shows the growth equation on household welfare and the average price of the selected food items. The growth equation shows a remarkable deceleration in the estimated quadratic time trend (b2), which was negative and significant for the household welfare and the average price of the selected food commodities.

The volatility of household welfare in Nigeria from 1990 to 2019

We tested for volatility in households' welfare (Household final consumption expenditure (N)) in Nigeria as specified in equations 3 and 4. The heteroscedasticity test presented in Table 3 shows the presence of conditional volatility or ARCH (Autoregressive Conditional Heteroscedasticity); this implies that there is the need to run a GARCH model.

Table 4 shows the result of the volatility test for household welfare, and the result shows the households' welfare status. The ARCH (RESID $\left.(-1)^{2}\right)$ and the GARCH $(\operatorname{GARCH}(-1))$ terms are

\begin{tabular}{lcccccc}
\hline Variable & $\mathrm{A}$ & $\mathrm{B}$ & $\mathrm{b} 2$ & $\mathrm{R} 2$ & $\mathrm{~F}$ & $\mathrm{R}$ \\
\hline HHW & $-7.40 \mathrm{E}+12$ & $5.55 \mathrm{E}+11$ & $-4.10 \mathrm{E}+09$ & 0.41 & $40.66 * * *$ & \\
& $(-4.57)^{* * *}$ & $(8.93)^{* * *}$ & $(-8.343) * * *$ & & & \\
\multirow{2}{*}{ AVPIF } & -359.646 & 992.576 & -3.963 & 0.93 & $734.90 * * *$ & 0.96 \\
& $(-0.25)$ & $(17.89) * * *$ & $(-8.923) * * *$ & & & \\
\hline
\end{tabular}

Note: $* * *$ indicates that the values are significant at $1 \%$

Source: Authors' Analysis Based on FAO and WDI

Table 2: Estimated growth in the trend of Household welfare and Average price of the selected food commodities.

\begin{tabular}{lccc}
\hline F-statistic & $1326.21 * * *$ & Prob. F $(1,117)$ & 0.00 \\
Obs*R-squared & $109.35 * * *$ & Prob. Chi-Square(1) & 0.00 \\
\hline
\end{tabular}

Note: $* * *$ indicates that the values are significant at $1 \%$

Source: Authors' Analysis Based on FAO and WDI

Table 3: Heteroskedasticity Test: ARCH. 


\begin{tabular}{|c|c|c|c|c|}
\hline Variable & Coefficient & Std. Error & z-Statistic & Prob. \\
\hline $\operatorname{AR}(1)$ & 0.44 & 8.59 & 0.05 & 0.96 \\
\hline $\operatorname{AR}(2)$ & 0.31 & 4.36 & 0.07 & 0.94 \\
\hline $\operatorname{AR}(3)$ & 0.25 & 6.84 & 0.04 & 0.97 \\
\hline $\operatorname{AR}(4)$ & 0.08 & 1.94 & 0.04 & 0.97 \\
\hline $\operatorname{MA}(1)$ & 0.65 & 8.61 & 0.08 & 0.93 \\
\hline $\operatorname{MA}(2)$ & 0.37 & 5.57 & 0.07 & 0.95 \\
\hline \multicolumn{5}{|c|}{ Variance Equation } \\
\hline $\mathrm{C}$ & $6.19 \mathrm{E}+25$ & $1.21 \mathrm{E}+25$ & $5.10 * * *$ & 0.00 \\
\hline $\operatorname{RESID}(-1)^{2}$ & 0.10 & 0.04 & $2.62 * *$ & 0.01 \\
\hline GARCH(-1) & -0.99 & 0.01 & $-328.84 * * *$ & 0.00 \\
\hline R-squared & 0.93 & Mean dependent var & & $6.17 \mathrm{E}+12$ \\
\hline Adjusted R-squared & 0.93 & S.D. dependent var & & $7.60 \mathrm{E}+12$ \\
\hline S.E. of regression & $2.09 \mathrm{E}+12$ & Akaike info criterion & & 60.27 \\
\hline Sum squared resid & $4.79 \mathrm{E}+26$ & Schwarz criterion & & 60.48 \\
\hline Log-likelihood & -3486.36 & Hannan-Quinn criteria. & & 60.35 \\
\hline Durbin-Watson stat & 2.03 & & & \\
\hline Inverted AR Roots & 1.04 & $-.13-.46 \mathrm{i}$ & $-.13+.46 \mathrm{i}$ & -.34 \\
\hline \multicolumn{5}{|c|}{ Estimated AR process is nonstationary. } \\
\hline Inverted MA Roots & $-.33+.51 \mathrm{i}$ & $-.33-.51 \mathrm{i}$ & & \\
\hline
\end{tabular}

Note: $* * *$ indicates that the values are significant at $1 \%$

Source: Authors' Analysis Based on FAO and WDI

Table 4: GARCH result in the volatility of household welfare.

significant at the 5\% level. The result shows that household welfare is volatile. The summation of the ARCH (0.104270) and GARCH (-0.992148) is very close to one, and this indicates that household welfare will continue to be volatile, and it is in line with a priori expectation. Observations show that inflations in Nigeria fluctuate and affect household spending patterns.

The volatility of the average price of the select food commodities in Nigeria

We test for the volatility of the average price of the selected food commodities in Nigeria, as specified in equations 3 and 4 . The heteroscedasticity test presented in Table 5 shows that there are the presences of conditional volatility or ARCH (Autoregressive Conditional Heteroscedasticity); this implies that there is a need to run a GARCH model.

\begin{tabular}{llll}
\hline F-statistic & $27.91 * * *$ & Prob. F(1,113) & 0.00 \\
Obs*R-squared & $22.78 * * *$ & Prob. Chi-Square(1) & 0.00 \\
\hline
\end{tabular}

Note: $* * *$ indicates that the values are significant at $1 \%$ Source: Authors' Analysis Based on FAO and WDI
Table 6 presents the volatility test result for the average price of the selected food commodities, and the result shows the average food price of the selected commodities. The GARCH (GARCH(-1)) terms are significant at the $5 \%$ level, which implies the possibility of a future forecast of the variance to be high for a prolonged time. The result shows that the average price of the selected food commodities is volatile in the long-run. The summation of the ARCH (-0.601548) and GARCH (-0.949755) is very close to one, and this shows that the average price of the selected essential food items will continue to be high and volatile.

Table 5: Heteroskedasticity Test: ARCH. 


\begin{tabular}{|c|c|c|c|c|}
\hline Variable & Coefficient & Std. Error & z-Statistic & Prob. \\
\hline $\mathrm{AR}(1)$ & 0.34 & 29.96 & 0.01 & 0.99 \\
\hline $\operatorname{AR}(2)$ & 0.23 & 71.48 & 0.01 & 0.99 \\
\hline $\operatorname{AR}(3)$ & 0.30 & 70.40 & 0.01 & 0.99 \\
\hline $\operatorname{AR}(4)$ & 0.14 & 8.61 & 0.02 & 0.99 \\
\hline MA(1) & 0.63 & 29.29 & 0.02 & 0.98 \\
\hline $\mathrm{MA}(2)$ & 0.28 & 54.81 & 0.02 & 0.99 \\
\hline \multicolumn{5}{|c|}{ Variance Equation } \\
\hline $\mathrm{C}$ & $1.34 \mathrm{E}+09$ & $2.92 \mathrm{E}+08$ & $4.60 * * *$ & 0.00 \\
\hline $\operatorname{RESID}(-1)^{2}$ & -0.60 & 2.84 & -0.21 & 0.83 \\
\hline GARCH(-1) & -0.95 & 0.04 & $-24.26 * * *$ & 0.00 \\
\hline R-squared & 0.96 & Mean dependent var & & 41823.20 \\
\hline Adjusted R-squared & 0.96 & S.D. dependent var & & 17813.89 \\
\hline S.E. of regression & 3795.12 & Akaike info criterion & & 22.16 \\
\hline Sum squared resid & $1.58 \mathrm{E}+09$ & Schwarz criterion & & 22.37 \\
\hline Log-likelihood & -1276.25 & Hannan-Quinn criteria. & & 22.25 \\
\hline Durbin-Watson stat & 1.98 & & & \\
\hline Inverted AR Roots & 1.00 & $-.13-.56 \mathrm{i}$ & $-.13+.56 \mathrm{i}$ & -.41 \\
\hline \multicolumn{5}{|c|}{ Estimated AR process is nonstationary. } \\
\hline Inverted MA Roots & $-.32+.42 \mathrm{i}$ & $-.32-.42 \mathrm{i}$ & & \\
\hline
\end{tabular}

Note: $* * *$ indicates that the values are significant at $1 \%$

Source: Authors' Analysis Based on FAO and WDI

Table 6: GARCH result for the volatility of the average food price.

Determinants of food price volatility on household welfare in Nigeria from 1990 to 2019

The bound test presented in Table 7 shows that a long-run relationship exists between the variables, making it necessary to estimate an ARDL model. The F-statistics value of 4.862 is higher than the lower I( 0$)$ and upper I( 1$)$ bound, which indicate the presence of a long-run relationship among the variables.

\begin{tabular}{lcc}
\hline Test Statistic & Value & $\mathrm{K}$ \\
\hline F-statistic & 4.86 & 9 \\
\hline Critical Value Bounds & & \\
\hline Significance & I0 Bound & I1 Bound \\
\hline $10 \%$ & 1.88 & 2.99 \\
\hline $5 \%$ & 2.14 & 3.3 \\
\hline $2.5 \%$ & 2.37 & 3.6 \\
\hline $1 \%$ & 2.65 & 3.97 \\
\hline
\end{tabular}

Source: Authors' Analysis Based on FAO and WDI

Table 7: Bound Test.

Table 8 shows the short-run ARDL model estimates. The estimates show that households' welfare in the 1st, 2nd, and 3rd lags were statistically significant at $1 \%$ and with a negative coefficient. This result implies that in the shortrun, changes in the household welfare in the past periods had a negative effect on household welfare (Household final consumption expenditure (N)). The average price of the selected food commodities is statistically significant at $1 \%$ and has a shortrun positive effect on household welfare. Minot and Dewina (2015), and Mbegalo and Yu (2016) reported that the price of food had a negative impact on household welfare in the short-run for Ghana and Tanzania, respectively, except if the households are producers of the food commodities. In Nigeria, agriculture has accounted for approximately 50 per cent of household revenues in the last ten years and employs 35.1 per cent of the households (World Bank, 2020). The households consume most of the food commodities produced. The households take advantage of the price of the food commodities produced to improve their welfare; this is because they sell some food commodities produced in the market to generate income. $\mathrm{Vu}$ and Glewwe (2011) reported that higher food prices in 2007 and 2008 globally resulted in improved household welfare in Vietnam because most households are agribusiness-based households.

Food price increase for non-agribusiness 


\begin{tabular}{lrrrr}
\hline Variable & \multicolumn{1}{c}{ Coefficient } & \multicolumn{2}{c}{ t-Statistic } & Prob. \\
\hline D(HHW(-1)) & -0.34 & 0.10 & $-3.53^{* * *}$ & 0.00 \\
D(HHW(-2)) & -0.34 & 0.10 & $-3.52^{* * *}$ & 0.00 \\
D(HHW(-3)) & -0.34 & 0.10 & $-3.52^{* * *}$ & 0.00 \\
D(CPIF) & -20811432310.94 & 15999086418.11 & -1.30 & 0.41 \\
D(AVPIF) & 135401122.30 & 34291837.70 & $3.95^{* * *}$ & 0.00 \\
D(DFD) & 285279206926.61 & 21293295178.21 & $13.40^{* * *}$ & 0.00 \\
D(DFD(-1)) & 258447945.00 & 35435137584.68 & 0.01 & 0.78 \\
D(DFD(-2)) & -140766975.05 & 35434744037.54 & -0.01 & 0.73 \\
D(DFD(-3)) & 111470405306.23 & 31913406396.36 & $3.49^{* * *}$ & 0.00 \\
D(ACF) & -390007104245.43 & 551713410533.26 & -0.71 & 0.57 \\
D(ELE) & 45815793604.32 & 53004503739.92 & 0.86 & 0.23 \\
D(EMP) & 324013.96 & 248797.23 & 1.30 & 0.02 \\
D(F.E. $)$ & -75225025745.38 & 134802468888.01 & -0.56 & 0.42 \\
D(F.I.) & -37077861351.36 & 28302548359.73 & 1.31 & 0.31 \\
D(FI(-1) & 2808055951.45 & 34837838456.01 & 0.08 & 0.55 \\
D(FI(-2)) & -60513273.71 & 34761926150.44 & -0.01 & 0.82 \\
D(FI(-3)) & 44819061950.95 & 26738246825.30 & 1.68 & 0.42 \\
D(FPI) & -9455347305.83 & 6646449994.29 & -1.42 & 0.44 \\
ECM(-1) & -0.01 & & -0.34 & 0.73 \\
\hline (E) & & 0.04 &
\end{tabular}

Note: ${ }^{*}, * *$,and $* * *$ indicates that the values are significant at $10 \%, 5 \%, 1 \%$ respectively

Source: Authors' Analysis Based on FAO and WDI

Table 8: ARDL (4, 0, 1, 4, 0, 0, 1, 0, 4, 0) Short-run coefficients.

households implies welfare decrease as they spend some resource meant to meet other aspects of their welfare on the purchase of food. The depth of food deficit is statistically significant at $1 \%$ and has a short-run positive effect on household welfare. Household consumption expenditure is a determinant of access to food. Food insecurity is a threat to poor households because they have limited food (FAO, 2013). The 3 rd lag of depth of food deficit is also significant at $1 \%$ and positively influences the household consumption expenditure. Households with food deficits experience seek remedy by channelling future income to meet household food needs. WHO (2006) reported that households with a very-low-income population like Nigeria are micronutrient deficient because of inadequate food intake. The Error Correction Term is the speed of adjustment of the variables returns to equilibrium because of a change in the model's other variables. The ECM coefficient of -0.007 shows that the rate of adjustment of the model variables is $0.07 \%$; it also indicates that the model is converging at equilibrium, and the estimated model is very stable.

The long-run coefficients in Table 9 were not statistically significant. In the long-run consumer price index (food indices), access to cooking fuel and gas, employment status, and food import have a negative coefficient. In the long-run, these variables have a negative impact on the household. The CPIF in Nigeria has been on the increase (Adetiloye, 2010). This result implies that in the long-run, households will spend more on food, and this increased expenditure on food will reduce the ability of the households' to spend on other necessities resulting in the decrease in household welfare. The households' access to cooking fuel and gas is limited due to the increase in the price (Gujba et al., 2015), which will have an adverse long-run impact on the household's welfare. Nigeria has a high unemployment rate; the negative coefficient of the long-run ARDL estimates implies that the households' employment status will result in a decrease in household consumption expenditure. Nigeria spends billions of Naira importing food, and households bear the costs of the imports by paying higher prices for imported foods. The negative coefficient of the long-run ARDL estimates shows that food imports result in decreased household welfare; this is because the households spend more on imported food and limiting their capacity to meet other welfare needs.

The average price of the selected food commodities, depth of food deficit, and access to electricity have positive coefficients, showing a positive household 


\begin{tabular}{lrrrr}
\hline Variable & \multicolumn{1}{c}{ Coefficient } & Std. Error & t-Statistic & Prob. \\
\hline CPIF & -1745571569839.72 & 5299087346563.38 & -0.33 & 0.74 \\
AVPIF & 4258466803.62 & 12647321060.75 & 0.34 & 0.74 \\
DFD & 519708482170.94 & 1449757430504.98 & 0.36 & 0.72 \\
ACF & -32712083581507.93 & 73175513970390.18 & -0.45 & 0.66 \\
ELE & 3842827613710.59 & 9031113341031.80 & 0.43 & 0.67 \\
EMP & -6873788.17 & 25380204.62 & -0.27 & 0.79 \\
FE & -6309544884739.75 & 26413259650338.22 & -0.24 & 0.81 \\
FI & -8526687345852.78 & 24716357175221.46 & -0.35 & 0.73 \\
FPI & -793073018398.08 & 2332649058914.13 & -0.34 & 0.72 \\
C & 237282314784740.22 & 1016429983640436.60 & 0.23 & 0.82 \\
\hline
\end{tabular}

Source: Authors' Analysis Based on FAO and WDI

Table 9: ARDL (4, 0, 1, 4, 0, 0, 1, 0, 4, 0) Long-run coefficients.

welfare influence. The increase in the average price of the selected food will increase the households' expenditure. The households cover their food deficit and increase their electricity access by spending more on nutrition and electricity to improve their welfare.

The Ramsey RESET test presented in Table 10 shows that the ARDL model is statistically stable. The t- statistics, and F-statistics are statistically significant at $1 \%$, indicating that the model is statistically significant.

\begin{tabular}{lccc}
\hline & Value & df & Probability \\
\cline { 2 - 4 } t-statistic & $6.22 * * *$ & 91 & 0.00 \\
F-statistic & $38.70 * * *$ & $(1,91)$ & 0.00 \\
\hline F-test summary: & & & \\
\hline \multirow{2}{*}{ Test SSR } & Sum of Sq. & df & Mean Squares \\
\cline { 2 - 4 } Restricted SSR & $3.78 \mathrm{E}+25$ & 1 & $3.78 \mathrm{E}+25$ \\
Unrestricted SSR & $1.27 \mathrm{E}+26$ & 92 & $1.38 \mathrm{E}+24$ \\
\hline
\end{tabular}

Note: $* * *$ indicate that the values are significant at 1

Source: Authors' Analysis Based on FAO and WDI

Table 10: Ramsey RESET Stability Test.

The Breusch-Godfrey Serial Correlation L. M. Test presented in Table 11 with an F-statistics value of 12.326 indicates that the model is free from serial correlation.

\begin{tabular}{llll}
\hline F-statistic & $12.33 * * *$ & Prob. F(2,91) & 0.00 \\
Obs*R-squared & $24.73 * * *$ & Prob. Chi-Square(2) & 0.00 \\
\hline
\end{tabular}

Note: $* * *$ indicate that the values are significant at $1 \%$.

Source: Authors' Analysis Based on FAO and WDI

Table 11: Breusch-Godfrey Serial Correlation L.M. Test.

The wald test presented in Table 12 shows that the explanatory variables are important and significant in the model with a chi-square value of 1410.627 , which significant at $1 \%$.

\begin{tabular}{lccc}
\hline Test Statistic & Value & Df & Prob. \\
\hline F-statistic & $156.7363 * * *$ & $(9,92)$ & 0.00 \\
Chi-square & $1410.627 * * *$ & 9 & 0.00 \\
\hline
\end{tabular}

Note: $* * *$ indicate that the values are significant at $1 \%$. Null Hypothesis: $\mathrm{C}(1)=0, \mathrm{C}(2)=0, \mathrm{C}(3)=0, \mathrm{C}(4)=0$, $\mathrm{C}(5)=0, \mathrm{C}(6)=0, \mathrm{C}(7)=0, \mathrm{C}(8)=0, \mathrm{C}(9)=0$

Source: Authors' Analysis Based on FAO and WDI Table 12. Wald Test.

\section{Conclusion}

The unit root test results show that the variables attained stationarity at a level or after differencing once. Thus, one may conclude that the variables are suitable for ARDL estimation. The occurrence of unit roots in the variables preliminarily test shows shocks having a permanent or long-lasting effect. The average price of the selected food items reflects the global hike in the price of food commodities in 2007/2008 before a decline in 2009. We expect the average price of the chosen food commodities to keep increasing through 2023. Already economic indicators show that Nigeria and many developing countries may not recover fully from the pandemic's impact in the next two years without adequate stimulus packages and incentives to the real sectors of the economy. Unfortunately, Nigeria's economy cannot support such investment and may likely slide into recession, leading to a further increase in food prices. The quadratic trend equation also shows that household welfare has experienced a remarkable deceleration. The price of the selected food commodities and household welfare were volatile. In the short-run average price of food and depth of food deficit were significant. In the long-run, the coefficients of the model 
variables were not statistically significant; this implies that the variables do not impact the households' welfare strongly in the longrun. As a critical policymaker, while formulating economic policies, the government should consider the fact that food prices are sensitive to changes in macroeconomic policies. This consideration is because any wrong macroeconomic policy results in a food price increase, which affects household expenditure. Efforts to curtail extreme spikes in the price of food commodities can substantially enhance the households' food security and overall economic welfare. Strategies for growth in household income are critical for improved access to foods in terms of quantity and diversity and households' overall economic well-being.

If policy actions complement food distribution and are sensitively guided by welfare-related interventions, more sustainable livelihoods can be achieved. Households spend most of their consumption expenditure on expensive food imports. Food importation can be reduced by increasing imported foods' local production; this will leave households with more income to probably save or invest. Access to electricity by the household has a positive coefficient in the short-run; this implies that households spend a fortune on electricity, increasing their consumption expenditure.

Electricity has been a source of concern for the governments in Nigeria. They should be a genuine liberalisation and privatisation of the power sector to give more competitors access. With increased competition in the power sector, there will be more electricity supply for household productivity and subsequent welfare. Policymakers should focus on the short-term benefits while formulating policies aimed at households' welfare; This is because policies aimed at the household level are more impactful in the short-run compared to the long-run.

Corresponding authors

Ndubuisi Onwusiribe Chigozirim, Ph.D.

Michael Okpara University of Agriculture Umudike, Abia State, Nigeria

Phone: +234806 372 4608,E-mail: onwusiribe.chigozirim@mouau.edu.ng

\section{References}

[1] Adetiloye, K. A (2010) "Exchange Rates and the Consumer Price Index in Nigeria: A Causality Approach", Journal of Emerging Trends in Economics and Management Sciences (JETEMS), Vol.1, No. 2, pp. 114-120. ISSN 2141-7024.

[2] Bawa, S., Abdullahi, I. S. and Ibrahim, A. (2016) "Analysis of inflation dynamics in Nigeria (1981 - 2015)”, CBN Journal of Applied Statistics, Vol. 7, No. 1(b), pp. 255-276. ISSN 2141-9272.

[3] Bollerslev, T. (1986) "Generalised Autoregressive Conditional Heteroskedasticity", Journal of Econometrics, Vol. 31, No. 3, pp.307-327. ISSN 0304-4076. DOI https://doi.org/10.1016/0304-4076(86)90063-1.

[4] Compton, J., Wiggins, S. and Keats, S. (2010) "Impact of the Global Food Crisis on the Poor: What is the Evidence?", London: Overseas Development Institute, Jan. 2010. [Online]. Available: www. odi.org.uk/resources/download/5187.pdf. [Accessed: 11 Feb. 2020].

[5] Díaz-Bonilla, E. (2016) "Volatile volatility: Conceptual and measurement issues related to price trends and volatility", In Kalkuhl, M., von Braun, J. and Torero, M., eds. "Food price volatility and its implications for food security and policy", Springer International Publishing. pp. 35-57. ISBN 978-3-319-28199-5. DOI 10.1007/978-3-319-28201-5_2.

[6] Egwuma, H., Ojeleye, O. A. and Adeola S. S. (2017) "What Determines Food Price Inflation? Evidence from Nigeria”, FUOYE Journal of Agriculture and Human Ecology, Vol. 1, No. 2, pp. 48-61. ISSN 2659-1294.

[7] FAO (2013) "Food Security and Nutrition in the Southern and Eastern Rim of the Mediterranean Basin", Food and Agriculture Organization of the United Nations FAO Regional Office for the Near East. pp. 1-72 E-ISBN 978-92-5-107494-7. [Online]. Available: http://www.fao.org/3/ a-i3206e.pdf. [Accessed: 07 Apr. 2020]. 
[8] FAO (2017) "The Future of Food and Agriculture-Trends and Challenges", Food and Agriculture Organization of the United Nations FAO Rome, pp. 1-180. ISSN 2522-722X. [Online]. Available: http://www.fao.org/3/a-i6583e.pdf [Accessed: 05 Apr. 2020].

[9] FAO and OECD (2011) "Price Volatility in Food and Agricultural Markets: Policy Responses", Policy Report including contributions by FAO, IFAD, IMF, OECD, UNCTAD, WFP, the World Bank, the WTO, IFPRI and the UN HLTF, 2 June [Online]. Available: http://www.amis-outlook.org/ fileadmin/templates/AMIS/documents/Interagency_Report_to_the_G20_on_Food_Price_Volatility. pdf [Accessed: 05 Apr. 2020].

[10] Gujba, H., Mulugetta, Y. and Azapagic, A. (2015) "The Household Cooking Sector in Nigeria: Environmental and Economic Sustainability Assessment", Resources, Vol. 4, No. 2., pp. 412-433. ISSN 2079-9276. DOI 10.3390/resources4020412.

[11] ICRW (2017) "Economic Impacts of Child Marriage: Work, Earnings and Household Welfare", International Center for Research on Women. [Online]. Available: https://www.icrw.org/wp-content/ uploads/2018/02/ICRW_Brief_WorkEarningsHousehold-1.pdf [Accessed: 03 Apr. 2020].

[12] IFPRI (2011) "Food price volatility: Implications for ACP countries", International Food Policy Research Institute. [Online]. http://www.acp.int/sites/acpsec.waw.be/files/BR25_Food\%20 volatility_Programme.pdf [Accessed: 03 Apr. 2020].

[13] Iwuagwu, O. (2012) "Food Shortages, Survival Strategies and the Igbo of Southeastern Nigeria during the Nigeria Civil War", The Journal of International Social Research, Vol.5, No. 2, pp. 280-289. ISSN 1307-9581.

[14] Mbegalo, T. and Yu, X. (2016) "The Impact of Food Prices on Household Welfare and Poverty in Rural Tanzania", Discussion Papers, No. 216, Georg-AugustUniversität Göttingen, Courant Research Centre - Poverty, Equity and Growth (CRC-PEG), Göttingen. [Online]. Available: http://hdl.handle.net/10419/148391 [Accessed: 03 Apr. 2020].

[15] Minot, N. and Dewina, R. (2013) "Impact of Food Price Changes on Household Welfare in Ghana", International Food Policy Research Institute, IFPRI Discussion Paper 01245. [Online]. Available: https://ebrary.ifpri.org/utils/getfile/collection/p15738coll2/id/127393/filename/127604.pdf [Accessed: 03 Apr. 2020]. DOI 10.2139/ssrn.2228922.

[16] Moratti, M. and Natali, L. (2012) "Measuring Household Welfare: Short Versus Long Consumption Modules”, Working Paper 2012-04, UNICEF Office of Research, Florence. [Online]. Available: https://www.unicef-irc.org/publications/pdf/iwp_2012_04.pdf [Accessed: 04 Mar. 2020].

[17] NSIP (2020) "The National Social Register of Poor and Vulnerable Households (PVHHs) Distribution by States", National Social Investment Programme. [Online]. Available: https://n-sip.gov.ng/national-update. [Accessed: 08 Mar. 2020].

[18] Ojo, E. O. and Adebayo, F. P. (2012) "Food Security in Nigeria: An Overview", European Journal of Sustainable Development, Vol. 1, No. 2, pp. 199-222. ISSN 2239-5938. DOI 10.14207/ejsd.2012.v1n2p199.

[19] Olomola, A. S. and Nwafor, M. (2018) "Nigeria Agriculture Sector Performance Review", International Institute of Tropical Agriculture (IITA). [Online]. Available: https://fscluster.org/sites/ default/files/documents/nigeria_agric_sector_review_report_august_2018.pdf [Accessed: 13 Mar. 2020].

[20] PARI (2015) "Nigeria: Potentials and Possibilities for German Collaboration in Agriculture", Program for Accompanying Research for Agricultural Innovation. [Online]. Available: https://research4agrinnovation.org/wp-content/uploads/2016/03/Nigeria.pdf. [Accessed: 08 Jan. 2020].

[21] Pesaran, M. H., Shin, Y. and Smith, R. J. (2001) "Bounds Testing Approaches to the Analysis of Level Relationships", Journal of Applied Econometrics, Vol. 16, No. 3, pp. 289-326. ISSN 1099-1255. DOI 10.1002/jae.616. 
[22] Pinstrup-Andersen, P. (2015) "Food Price Policy in an Era of Market Instability: A Political Economy Analysis", UNU-WIDER Studies in Development Economics, Oxford University Press, Oxford. ISBN 978-0-19-871857-4. DOI 10.1093/acprof:oso/9780198718574.001.0001.

[23] Popović, B. Č. (2011) "Heteroscedastic Time Series", In: Lovric M. (eds) "International Encyclopedia of Statistical Science", Springer, Berlin, Heidelberg. ISBN 978-3-642-04897-5. DOI 10.1007/978-3-642-04898-2 287.

[24] SIFSIA-N/FAO (2008) "Determinants of Current Food Price Hikes and their Implications in the Northern States of Sudan", Sudan Integrated Food Security Information for Action-North Sudan and Food and Agriculture Organization. [Online]. Available: http://www.fao.org/fileadmin/ user_upload/sifsia/docs/Food\%20Price\%20Hikes\%20and\%20Impacts\%20in\%20NS\%20-\%20 Jan\%202009.pdf. [Accessed: 13 Jan. 2020].

[25] Taru, B. (2014) "Price Fluctuation and Market Integration of Selected Cereal in North-Eastern Nigeria, 2001-2010", Thesis submitted to the Department of Agricultural Economics, Faculty of Agriculture, University of Nigeria, Nsukka. [Online]. Available: http://www.unn.edu.ng/ publications/files/Taru\%20PhD\%20Thesis\%20-market\%20...pdf .[Accessed: 12 Feb. 2020].

[26] Udoh, E., Afangideh, U. and Udeaja, E. A. (2015) "Fiscal Decentralisation, Economic Growth and Human Resource Development in Nigeria: Autoregressive Distributed Lag (ARDL) approach", CBN Journal of Applied Statistics, Vol. 6, No.1, pp. 69-93. ISSN 2141-9272.

[27] Vu, L. and Glewwe, P. (2011) "Impacts of Rising Food Prices on Poverty and Welfare in Vietnam", Journal of Agricultural and Resource Economics, Vol. 36, No.1, pp. 14-27. ISSN 1068-5502.

[28] World Bank (2019) "Population Growth Rate (Annual \%)",The World Bank. [Online]. Available: https://data.worldbank.org/indicator/sp.pop.grow. [Accessed: 12 Feb. 2020].

[29] World Bank (2020) "Employment in agriculture (\% of total employment) (modelled ILO estimate) - Nigeria”, The World Bank. [Online]. Available: https://data.worldbank.org/indicator/SL.AGR. EMPL.ZS?locations=NG. [Accessed: 12 Feb. 2020].

[30] WHO (2006) "Guidelines on food fortification with micronutrients", World Health Organization, Geneva, Switzerland. [Online]. Available: https://www.who.int/nutrition/publications/guide_food_ fortification_micronutrients.pdf. [Accessed: 11 Jan. 2020]. 